\title{
MERCURY AND OTHER TRACE ELEMENTS IN GLACIAL MELTWATER AT GRAND TETON NATIONAL PARK, WYOMING
}

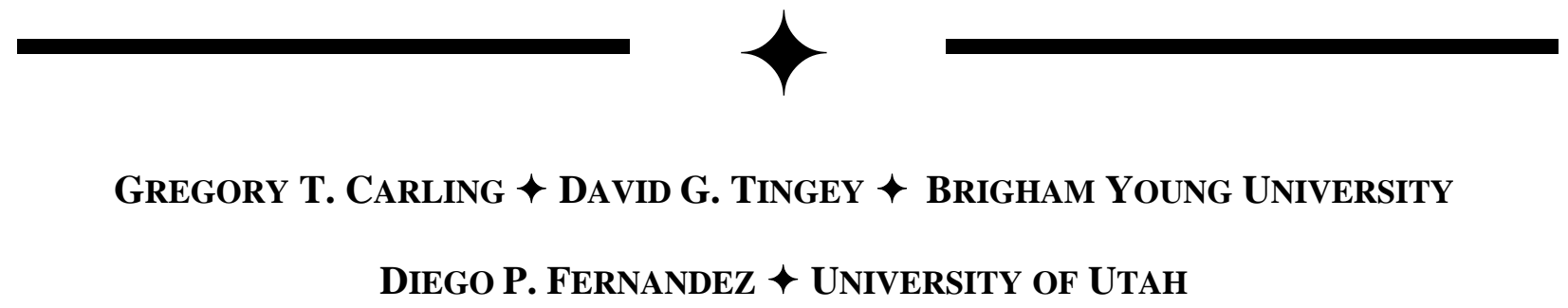

\section{$\uparrow \quad$ ABSTRACT}

Glaciers are a reservoir of mercury $(\mathrm{Hg})$ and other trace elements that have accumulated in the ice during the industrial era. As glaciers continue to melt at an alarming rate, these potentially toxic metals are released to the environment. In order to evaluate the impact of glacier melt on water quality in high elevation catchments in Grand Teton National Park, we sampled transects along the Teton and Middle Teton glaciers and proglacial streams during earlyJuly and mid-August 2013. The glaciers were snowcovered during July, and thus water samples were primarily melt of snowpack from the previous winter. The glacier ice was exposed during August, and thus samples likely represented true glacier melt. These contrasting sample sets allowed for a determination of the impact of snowmelt versus glacier melt on water chemistry. Ten samples were collected during July and August along the Glacier Gulch transect: four of surface drainage on the Middle Teton glacier, three near the terminal moraine, and three downstream of the glacier. Thirteen samples were collected during July and August along the Garnet Canyon transect: one at the Lower Saddle of the Grand Teton, four of surface drainage on the Middle Teton glacier, two near the terminal moraine, two at the moraine of Teepe Glacier, and four samples downstream of the glaciers. All water samples were analyzed for total $\mathrm{Hg}$, a suite of trace elements (including $\mathrm{U}, \mathrm{Sr}$, and $\mathrm{Mn}$ ), and stable water isotopes $\left(\delta^{2} \mathrm{H}\right.$ and $\left.\delta^{18} \mathrm{O}\right)$. Analyses for methyl $\mathrm{Hg}$, solutes, and tritium $\left({ }^{3} \mathrm{H}\right)$ are still underway. Preliminary results indicate that snowmelt and glacier melt was a significant source of total $\mathrm{Hg}$, but additional work is needed to determine the extent of
Hg methylation in the proglacial streams. Other trace elements were found in low concentrations in the melt water, but increased substantially downstream of the glaciers due to water-rock interactions.

\section{$\uparrow \quad$ INTRODUCTION}

The retreat of glaciers worldwide may lead to the rapid release of mercury and other trace metals to high elevation aquatic ecosystems (Barbante et al. 2004, Hong et al. 2004, Schuster et al. 2002). Mercury is a toxic element that is deposited to aquatic systems primarily by atmospheric deposition. Due to enhanced orographic-driven wet and dry deposition at high elevations, glaciers likely receive disproportionately high mercury loads (Carling et al. 2012, Fortner et al. 2011, Reynolds et al. 2010). In an ice core from the Wind River Range in Wyoming, Schuster et al. (2002) found elevated mercury concentrations in ice from the 1700 s to present day, with a maximum during the 1960s to 1980s (Figure 1). They attributed the increased mercury deposition to mining and industrialization during the $19^{\text {th }}$ and $20^{\text {th }}$ centuries. Likewise, sediment cores collected from remote, high elevation lakes in Rocky Mountain National Park (Colorado) and Glacier National Park (Montana) showed an increase in mercury concentrations beginning in the 1900 s, with a peak sometime after 1980 (Mast et al. 2010). Huang et al. (2012) showed that glaciers on the Tibetan Plateau are currently an important sink in the global mercury cycle, but they hypothesized that with a warming climate the glaciers may become a mercury source that could endanger ecosystems and human health in the region. This may 
already be happening in other locations, including the Canadian Rockies, where melting glaciers and snowpack may be a source of mercury to osprey that live at high elevations (Guigueno et al. 2012).

In addition to mercury, glacial melt may be a source of other harmful trace elements (e.g., lead, arsenic, uranium) to pristine high elevation watersheds. Trace elements are deposited to alpine environments via wet deposition, but a majority of these elements are deposited by wind-blown dust. Carling et al. (2012) found that concentrations of mercury, lead, and arsenic increased by a factor of five or greater in Wasatch Mountain (Utah) snowpack after dust deposition. Likewise, Reynolds et al. (2010) measured elevated concentrations of lead in sediment cores from remote Uinta Mountain lakes in northeastern Utah, which they attributed to dust emission from mining areas located $>100 \mathrm{~km}$ away. In a study at Mt. Hood, Oregon, Fortner et al. (2009) found that trace metals were released from glacier melt, and that a portion of these metals were derived from distal anthropogenic sources. Receding glaciers also expose readily-weathered fresh bedrock and glacial till. For example, retreating glaciers in the Cordillera Blanca of Peru have exposed sulfide-rich bedrock, which has led to acidic runoff with high trace metal concentrations (Fortner et al. 2011).

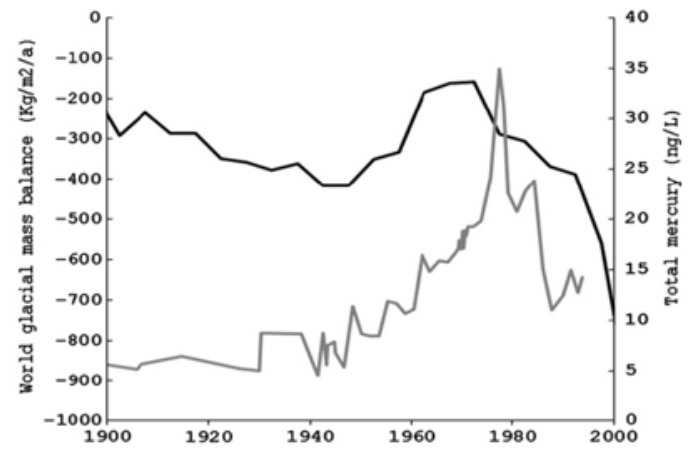

Figure 1. Worldwide cumulative glacier volume relative to 1850 excluding the Antarctic and Greenland ice sheetsblack line (Cogley 2009), and mercury concentrations in the Upper Fremont Glacier, Wyoming from 1900 to 2000 - gray line (Schuster et al. 2002). Adapted from Guigueno et al. (2012).

In Wyoming, as in other areas around the world, glaciers are receding at an alarming rate. Wyoming is the second most glaciated state in the lower 48, and glaciers contribute to the headwaters of some of North America's major river systems. The Wind River Range of Wyoming is the most glaciated region in the American Rockies, yet total glacier surface area decreased by 38\% from 1966 to 2006 (Thompson et al. 2011). Recent research has shown that the melt rates have increased even more since 2006 (VanLooy et al. 2012). Glacier melt contributes as much as $50 \%$ of total streamflow to high alpine streams in the Wind Rivers, and thus shrinking glacier reserves may lead to water shortages in the future (Cable et al. 2011). Glaciers in the nearby Teton Range have retreated at a similar rate over the past four decades, with the Teton, Middle Teton, and Teepe glaciers losing $17 \pm 3 \%, 25 \pm 4 \%, 60 \pm 3 \%$ of their surface area, respectively, between 1967 and 2006 (Edmunds et al. 2012).

As the rate of glacier melt continues to accelerate (Figure 1), the impact that trace metals in the meltwater pulse may have on downstream ecosystems is poorly understood. We hypothesized that water quality downstream of glaciers could be degraded as centuries' worth of contaminants are released over the span of a few decades. Also, we hypothesized that water quality could be negatively impacted due to interactions with fresh bedrock and glacial till that are exposed by the retreating glaciers. To test these hypotheses, we evaluated water chemistry of proglacial streams (i.e., streams that drain glaciers) in Grand Teton National Park (GTNP) in order to develop baseline criteria on concentrations of mercury and other trace elements in glacier melt. Ultimately, this study has implications for water quality and ecosystem ecology of glaciated areas worldwide. Specific objectives of this research were to:

1. Evaluate concentrations of mercury and other trace elements in glacier-dominated catchments at GTNP;

2. Evaluate seasonal variability in the chemistry of snow and glacier melt;

3. Evaluate relative contributions of trace elements from glacier melt, snowmelt, and water-rock interactions.

\section{$\uparrow \quad$ METHODS}

\section{Sample collection}

Water samples were collected from supraglacial and proglacial streams in Garnet Canyon and Glacier Gulch during July and August 2013. During the July sampling (July 2 and 5) the glaciers were covered with snowpack from the previous winter. During the August sampling (August

14 and 16) much of the seasonal snowpack was melted and ice was exposed at the surface. This field sampling design allowed for evaluation of water chemistry under snowmelt-dominated conditions during July and ice melt-dominated conditions of August. 


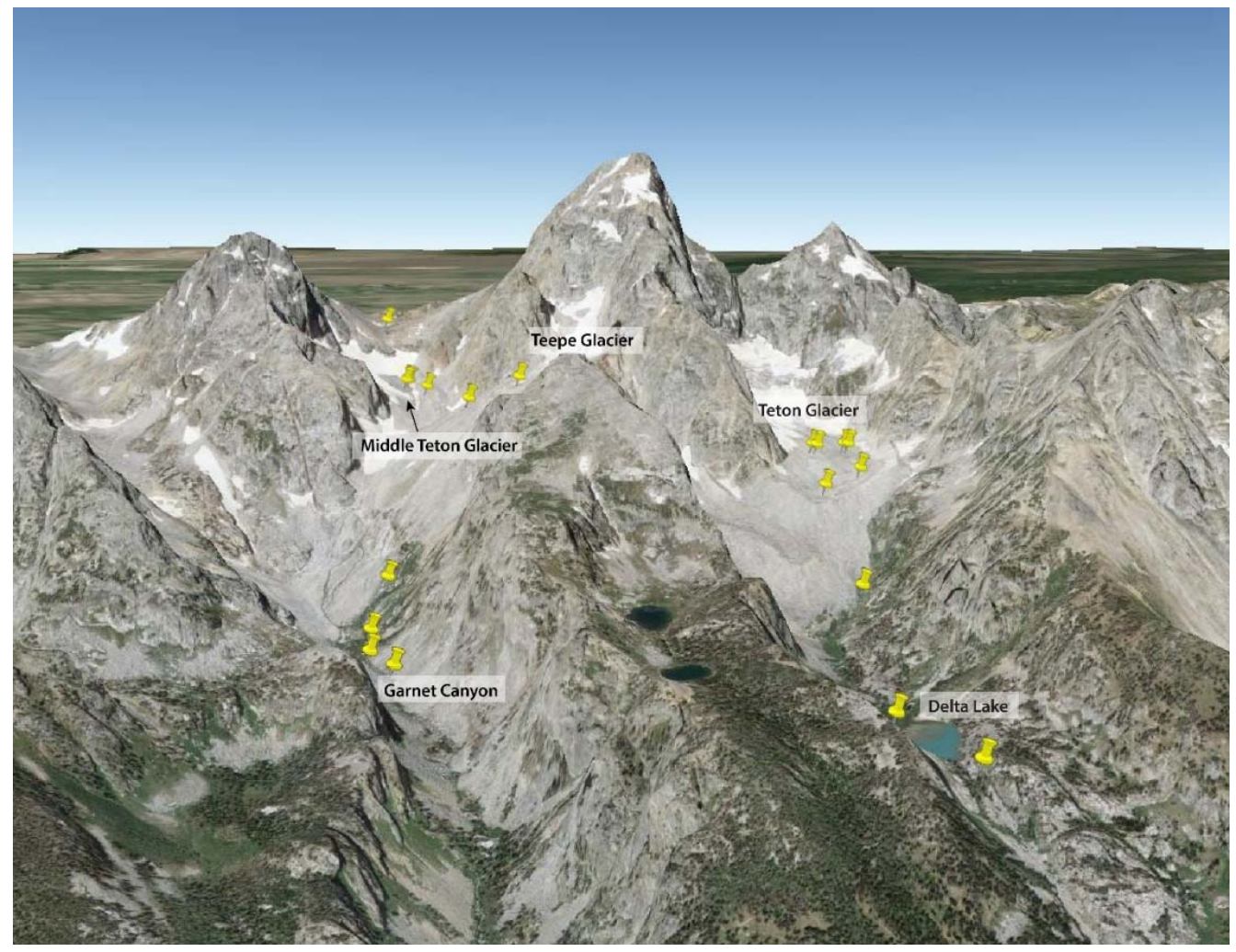

Figure 2. Tilted Google Earth image showing sample sites (yellow pins) on and below the Middle Teton, Teepe, and Teton glaciers. Image taken 3 August 2013, about midway between the two sampling events.
The Garnet Canyon transect included one sample near the Lower Saddle of the Grand Teton, four samples of supraglacial melt channels on the Middle Teton Glacier, one sample of supraglacial melt on the Teepe Glacier, samples at the terminal moraine of each glacier, and four samples downstream in Garnet Canyon terminating below the Meadows campsite (Figure 2). The Glacier Gulch transect included four samples of supraglacial melt on the Teton Glacier, two samples at the terminal moraine of the glacier, and three samples downstream in Glacier Gulch terminating below Delta Lake (Figure 2).

Well-established methods were followed for sample collection and handling (Carling et al. 2011, Carling et al. 2012, Carling et al. 2013a, Carling et al. 2013b). To cover all the sampling sites in each transect in a single day, we divided into two teams of two people to collect the samples. Each team followed strict "clean hands/dirty hands" protocols as outlined in EPA Method 1669. At each site, separate bottles were used to collect samples for mercury $(250 \mathrm{~mL}$ FLPE), trace elements (125 mL LDPE), and stable water isotopes (1L LDPE). Upon returning to the field station at the end of each sampling day, samples were filtered $(0.45 \mu \mathrm{m})$ into separate bottles and acidified $\left(1 \% \mathrm{v} / \mathrm{v} \mathrm{HCl}\right.$ for mercury samples and $2.4 \% \mathrm{HNO}_{3}$ for trace element samples).
In addition to water samples, each team measured field parameters $(\mathrm{pH}$, water temperature, and conductivity) at each site using a YSI Quatro multi-parameter probe. The probe was calibrated at the field station prior to each sampling day.

On each sampling day, each team collected a field blank by pouring Milli-Q water into empty 250 $\mathrm{mL}$ FLPE and $125 \mathrm{~mL}$ LDPE bottles. The field blank samples $(n=4)$ were used to determine background contamination during sample collection and sample handling. Field blanks showed no significant contamination for any of the measured elements.

\section{Sample analyses}

Mercury samples were analyzed using an automated Brooks Rand CVAFS at Brigham Young University. All samples were analyzed for total $\mathrm{Hg}$ (THg), but analyses are still underway for methyl $\mathrm{Hg}$ (MeHg). THg concentrations were determined according to EPA Method 1631 e with $\mathrm{BrCl}$ oxidation. At a minimum, matrix spike recoveries and replicates were analyzed for every 10 samples. For the sample run to be accepted, matrix spike recoveries had to fall within $75-125 \%$ of the original sample run and replicate analyses had to fall within $\pm 10 \%$. Method blanks were analyzed at the beginning of each run in order to calculate a daily detection limit. Typical 
values of the detection limit were $0.2 \mathrm{ng} / \mathrm{L}$ for $\mathrm{THg}$. To check accuracy, our laboratory participated in the 2014 Brooks Rand Labs Interlaboratory Comparison Study with results within $\pm 10 \%$ of the most probable values.

Trace element samples were analyzed using an Agilent 7500ce quadrupole inductively coupled plasma mass spectrometer (ICP-MS) at the University of Utah. Concentrations were measured for the following 40 elements: $\mathrm{Ag}, \mathrm{Al}, \mathrm{As}, \mathrm{Ba}, \mathrm{Be}, \mathrm{Ca}, \mathrm{Cd}, \mathrm{Ce}$, $\mathrm{Co}, \mathrm{Cr}, \mathrm{Cs}, \mathrm{Cu}, \mathrm{Dy}, \mathrm{Fe}, \mathrm{Gd}, \mathrm{Ho}, \mathrm{K}, \mathrm{La}, \mathrm{Li}, \mathrm{Lu}, \mathrm{Mg}$, $\mathrm{Mn}, \mathrm{Mo}, \mathrm{Na}, \mathrm{Nd}, \mathrm{Ni}, \mathrm{Pb}, \mathrm{Rb}, \mathrm{Sb}, \mathrm{Sc}, \mathrm{Se}, \mathrm{Sm}, \mathrm{Sr}, \mathrm{Tb}$, $\mathrm{Ti}, \mathrm{Tl}, \mathrm{U}, \mathrm{V}, \mathrm{Y}$, and $\mathrm{Zn}$. A calibration solution containing all the elements reported was prepared gravimetrically using $1000 \mathrm{mg} / \mathrm{L}$ single-element standards (Inorganic Ventures, Inc.). This solution was used to prepare a calibration curve with six points plus a blank for each sample run. $\mathrm{Al}, \mathrm{Ca}, \mathrm{Cr}, \mathrm{Fe}, \mathrm{K}, \mathrm{Mn}$, $\mathrm{Na}, \mathrm{Sc}$, and $\mathrm{V}$ were determined using $4 \mathrm{~mL} \mathrm{He} / \mathrm{min}$ in the collision cell, and As and Se were determined using $4 \mathrm{~mL} \mathrm{He} / \mathrm{min}$ plus $2.5 \mathrm{~mL} \mathrm{H}_{2} / \mathrm{min}$. The detection limit was determined as three times the standard deviation of all blanks analyzed throughout each run. A USGS standard reference sample (T-205) and NIST standard reference material (SRM 1643e) were analyzed multiple times in each run together with the samples as a continuing calibration verification. The long term reproducibility for T-205 and SRM 1643e show that our results are accurate within $10 \%$ for most elements.

Stable water isotopes $\left(\delta^{18} \mathrm{O}\right.$ and $\left.\delta^{2} \mathrm{H}\right)$ were measured on unfiltered aliquots from the $1 \mathrm{~L}$ LDPE bottle using a Los Gatos Research Liquid Water Isotope Analyzer (LWIA-24d) at Brigham Young University. All measurements were made relative to Vienna Standard Mean Ocean Water (VSMOW), with a precision of $0.4 \%$ and $1.0 \%$ for $\delta^{18} \mathrm{O}$ and $\delta^{2} \mathrm{H}$, respectively. Analyses for tritium $\left({ }^{3} \mathrm{H}\right)$ and solutes are still underway, but should be completed by the end of August 2014.

\section{$\downarrow \quad$ PRELIMINARY RESULTS}

\section{Stable water isotopes}

All water samples plotted on or near the global meteoric water line (GMWL), indicating little influence of evaporation or sublimation during transport from the glaciers to proglacial streams (Figure 3). Samples collected during July and August had substantially different water isotope signatures as a whole, with August samples plotting toward heavier isotopic values on the GMWL relative to the July samples (Figure 3). This provides evidence that the July and August sampling events successfully captured different hydrologic regimes, with snowmeltdominated conditions in July and ice melt-dominated conditions in August. The difference in isotopic composition of July and August samples will be investigated more fully in the future. One hypothesis for the heavier isotopic signatures in August relative to July is that the glacial ice is an accumulation of winter (lighter isotopes) and summer (heavier isotopes) precipitation, whereas the snowmelt represents only winter precipitation.

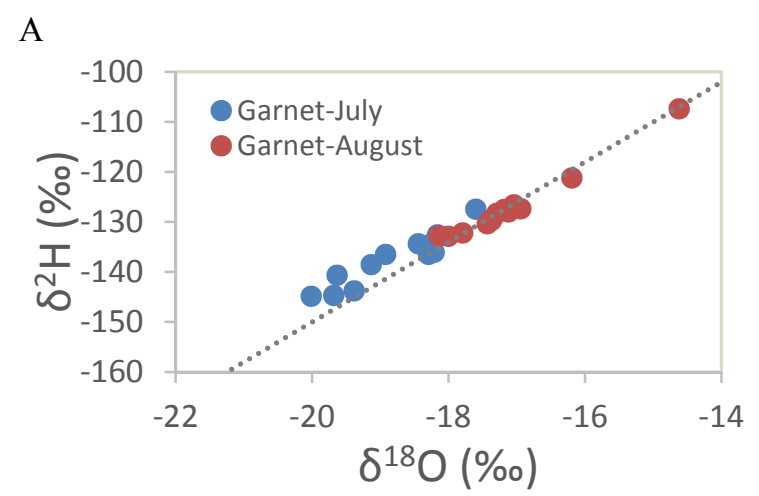

B

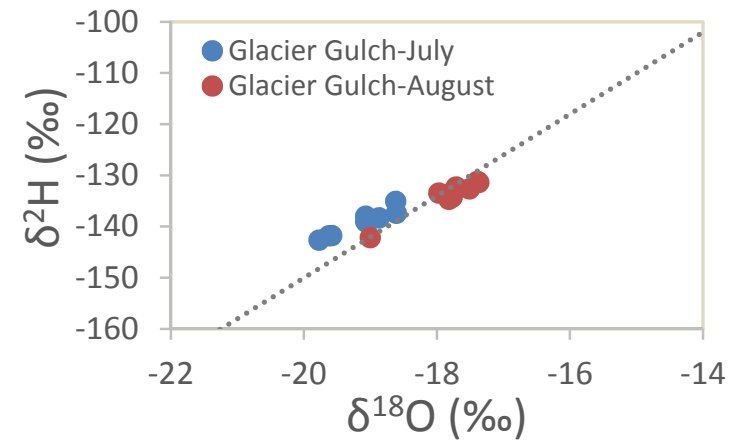

Figure 3. Stable isotopes of water samples collected at (A) Garnet Canyon and (B) Glacier Gulch. July and August data are shown as blue and red circles, respectively. Values are relative to VSMOW. The dotted line is the global meteoric water line.

\section{Mercury and other trace elements}

Figure 4 shows concentrations of mercury $(\mathrm{Hg})$ and selected trace elements at the Garnet Canyon transect (Figure 4A) and Glacier Gulch transect (Figure 4B). In order to more easily interpret mercury and trace element results, samples from each transect were grouped according to location. At the Garnet Canyon transect, the groups were the saddle $(n=1)$, supraglacial melt streams on the Middle Teton Glacier $(n=4)$, the Teepe Glacier moraine $(n=2)$, above the Meadows camp site $(\mathrm{n}=2)$, and below the Meadows 
camp site $(n=2)$. At the Glacier Gulch transect, the groups were supraglacial melt streams on the Teton Glacier $(n=4)$, the terminal moraine $(n=2)$, below the moraine $(n=1)$, above Delta Lake $(n=1)$, and below Delta Lake $(\mathrm{n}=1)$.

Hg concentrations were low $(<1 \mathrm{ng} / \mathrm{L})$ in both the Garnet Canyon and Glacier Gulch transects. At Garnet Canyon, concentrations were highest in the Saddle and supraglacial melt samples and lowest downstream (Figure 4A). At Glacier Gulch, Hg concentrations were similar at all sample sites (Figure 4B). There were no significant differences in $\mathrm{Hg}$ concentrations between July and August, indicating that melt from snowpack and glaciers contribute similar amounts of $\mathrm{Hg}$ to the stream systems in both catchments. The similar concentrations in the supraglacial melt channels and downstream samples indicates that atmospheric deposition is likely an important contributor of $\mathrm{Hg}$ to the watershed, and that water-rock interactions do not add substantial amounts of $\mathrm{Hg}$ to the system.

Although the concentrations of total $\mathrm{Hg}$ were low, there still may be a threat to downstream ecosystems if the inorganic $\mathrm{Hg}$ has potential to be methylated. Even low methyl $\mathrm{Hg}$ concentrations can be toxic to wildlife and cause harm to humans who consume fish from high alpine lakes. Preliminary results show that methyl $\mathrm{Hg}$ concentrations are low in the supraglacial melt channels but increase substantially downstream. More samples need to be analyzed in order to confidently show whether the apparent increases are significant. Other elements with interesting trends include uranium (U), strontium (Sr), and manganese (Mn). U concentrations were low near the glaciers but increased dramatically in the downstream samples in both catchments, with similar results during July and August (Figure 4). Low U concentrations in the glaciers and relatively high concentrations downstream indicates that $U$ is dissolved into the stream as a result of water-rock interactions. Higher concentrations in Garnet Canyon relative to Glacier Gulch are likely a result of increased water-rock contact time. Thus the metamorphic or igneous bedrock likely contain Ubearing minerals that release uranium during weathering processes. More work is needed to determine which rocks and minerals in Garnet Canyon and Glacier Gulch contain U.

Sr showed a similar trend as U, but with some notable exceptions. Sr concentrations were low in the supraglacial melt channels and increased substantially downstream, with higher concentrations in Garnet Canyon relative to Glacier Gulch (Figure 4). This indicates that water rock interactions are likewise controlling $\mathrm{Sr}$ distribution. However, $\mathrm{Sr}$ concentrations were also relatively high at the Saddle in Garnet Canyon and at the moraine at Glacier Gulch (where U concentrations were low). This indicates that the local groundwater may contain relatively high concentrations of $\mathrm{Sr}$ since these sites are likely springfed.

Mn concentrations were somewhat of an anomaly compared with the other measured elements. Mn concentrations were relatively high in supraglacial meltwater, especially on the Middle Teton Glacier (Figure 4). This indicates that atmospheric deposition is likely an important source of $\mathrm{Mn}$ to these catchments, probably in the form of aeolian dust. Mn was also notable because concentrations were higher in August relative to July at most samples sites (Figure 4). The seasonal differences were most pronounced below the Teton Glacier in Glacier Gulch, where Mn concentrations were a factor of 10 higher in August relative to July. This may indicate that the glacier melt contains higher Mn concentrations relative to seasonal snowmelt, but more work is needed to determine the cause of these trends. 
A
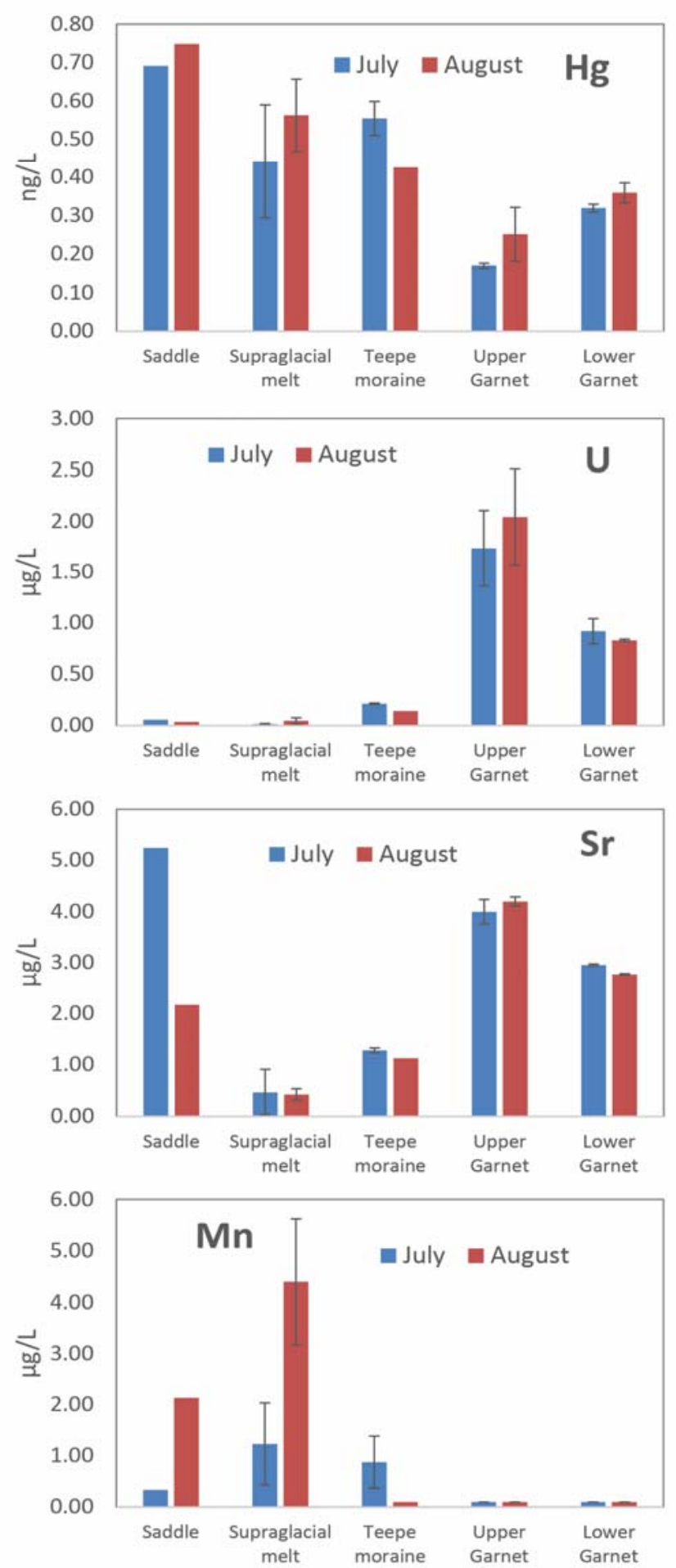

B
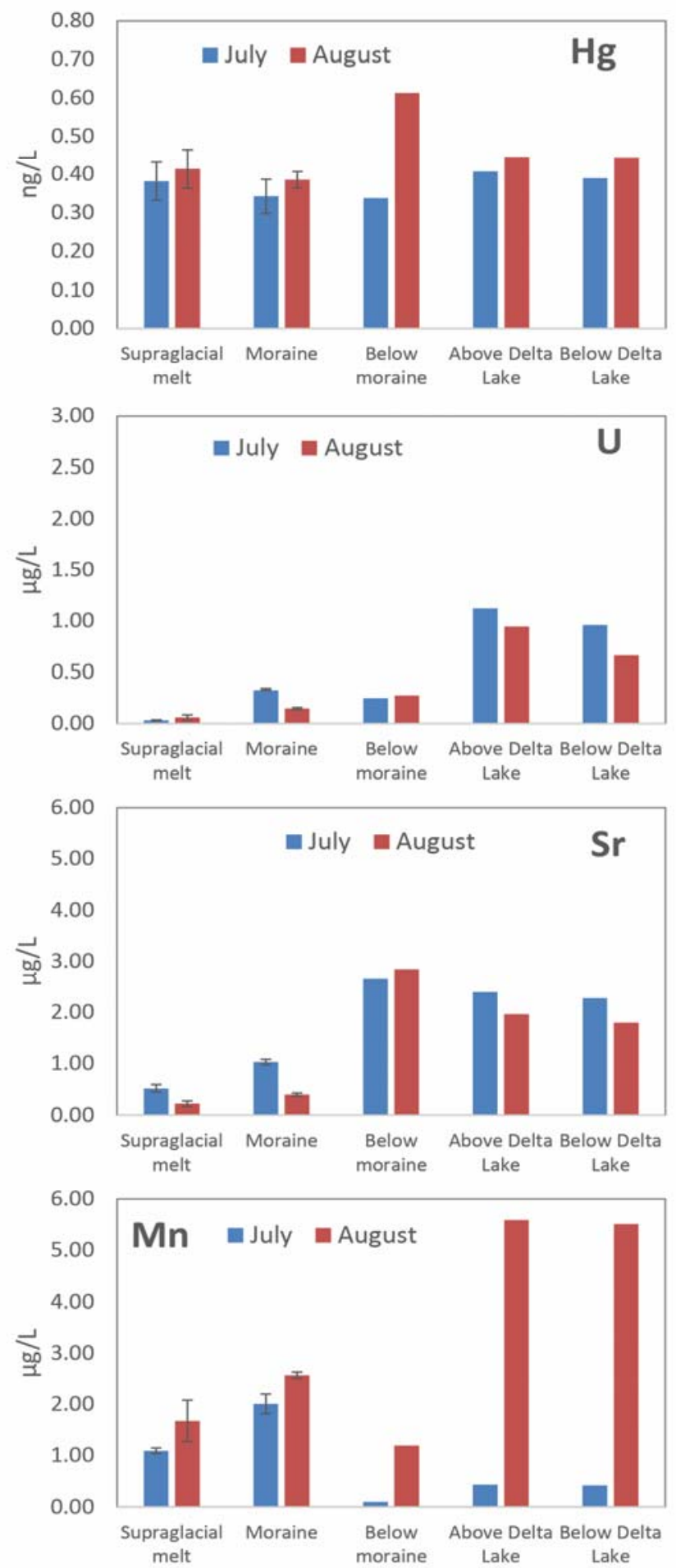

Figure 4. Trace element concentrations in filtered water samples collected at (A) Garnet Canyon and (B) Glacier Gulch. July and August data are shown as blue and red bars, respectively. Concentrations are $\mathrm{ng} / \mathrm{L}$ for $\mathrm{Hg}$ and $\mu \mathrm{g} / \mathrm{L}$ for $\mathrm{U}$, $\mathrm{Sr}$, and $\mathrm{Mn}$. Error bars show average and standard deviation for sample types that included more than one sample. 


\section{MANAGEMENT IMPLICATIONS}

Meltwater from the Middle Teton, Teepe, and Teton Glaciers appears to be a significant source of inorganic $\mathrm{Hg}$ to Garnet Canyon and Glacier Gulch. If $\mathrm{Hg}$ from the glacier is converted to methyl $\mathrm{Hg}$, it could pose a threat to downstream ecosystems. In contrast, most of the other measured elements were found in low concentrations in the supraglacial meltwater and were contributed mainly from interactions with bedrock downstream of the glaciers. We found no significant differences between the chemistry of snowmelt (July samples) and glacier melt (August samples), indicating that there is no extra source of $\mathrm{Hg}$ and other trace elements in the older ice relative to recent snowfall.

Continued monitoring of water quality is necessary to protect wildlife in snowmelt dominated catchments across GTNP under a warming climate. Changes in the timing and extent of snowmelt, shrinking glaciers, and other factors could result in negative impacts on the quality and quantity of water in streams, lakes, and wetlands in the Park. For example, as glaciers continue to recede, seasonal snowmelt will interact with bedrock and glacial till to a greater extent. Increased water-rock interactions could lead to higher concentrations of harmful trace elements such as uranium downstream of the glaciers. A long-term monitoring system at selected locations would allow GTNP scientists to evaluate the impacts of melting glaciers on water quality over the long term.

\section{$\uparrow \quad$ ACKNOWLEDGEMENTS}

In addition to support from the UW-NPS Research Station, this project has received funding from the College of Physical and Mathematical Sciences and the Department of Geological Sciences at Brigham Young University. Design and coordination of the field work benefited greatly from the staff at the Research Station and GTNP. We thank BYU students Cameron Harrison, Joel Johansen, Brian Selck, Dylan Dastrup, Desmond O'Brien, and Timothy Goodsell for field and laboratory assistance.

\section{$\downarrow$ LiteratuRe CiTED}

Barbante, C., M. Schwikowski, T. Doring, H.W. Gaggeler, U. Schotterer, L. Tobler, and C.Boutron. 2004. Historical record of European emissions of heavy metals to the atmosphere since the 1650 s from alpine snow/ice cores drilled near Monte Rosa.
Environmental Science \& Technology 38.15: 4085-4090.

Cable, J., K. Ogle, and D. Williams. 2011. Contribution of glacier meltwater to streamflow in the Wind River Range, Wyoming, inferred via a Bayesian mixing model applied to isotopic measurements. Hydrological Processes 25(14): 2228-2236.

Carling, G. T., D.P. Fernandez, A. Rudd, E. Pazmino, and W. P. Johnson. 2011. Trace element diel variations and particulate pulses in perimeter freshwater wetlands of Great Salt Lake, Utah. Chemical Geology 283(1): 87-98.

Carling, G. T., D. P. Fernandez, and W. P. Johnson. 2012. Dust-mediated loading of trace and major elements to Wasatch Mountain snowpack. Science of the Total Environment 432: 65-77.

Carling, G. T., X. Diaz, M. Ponce, L. Perez, L. Nasimba, E. Pazmino, and W.P. Johnson. 2013a. Particulate and dissolved trace element concentrations in three southern Ecuador rivers impacted by artisanal gold mining. Water, Air, and Soil Pollution 224(2): 1-16.

Carling, G. T., D.C. Richards, H. Hoven, T. Miller, D. P. Fernandez, A. Rudd, and W. P Johnson. 2013b. Relationships of surface water, pore water, and sediment chemistry in wetlands adjacent to Great Salt Lake, Utah, and potential impacts on plant community health. Science of the Total Environment 443: 798-811.

Cogley, J. G. 2009. Geodetic and direct mass-balance measurements: Comparison and joint analysis. Annals of Glaciology 50(50): 96100.

Edmunds, J., G. Tootle, G. Kerr, R. Sivanpillai, and L. Pochop. 2012. Glacier variability (19672006) in the Teton Range, Wyoming, United States. Journal of the American Water Resources Association 48(1): 187-196.

EPA Method 1669: Sampling ambient water for trace metals at EPA water quality criteria levels. July, 1996. 33 pp.

EPA Method 1631, Revision E: Mercury in water by oxidation, purge and trap, and cold vapor atomic fluorescence spectrometry. August 2002. $38 \mathrm{pp}$.

Fortner, S. K., W.B. Lyons, A. G. Fountain, K. A. Welch, and N. M. Kehrwald. 2009. Trace element and major ion concentrations and dynamics in glacier snow and melt: Eliot Glacier, Oregon Cascades. Hydrological Processes 23(21): 2987-2996. 
Fortner, S. K., B. G. Mark, J. M. McKenzie, J. Bury, A. Trierweiler, M. Baraer, and L. Munk. 2011. Elevated stream trace and minor element concentrations in the foreland of receding tropical glaciers. Applied Geochemistry 26(11): 1792-1801.

Guigueno, M. F., K. H. Elliot, J. Levac, M. Wayland, and J. E. Elliot. 2012. Differential exposure of alpine ospreys to mercury: Melting glaciers, hydrology or deposition patterns? Environment International 40: 24-32.

Hong, S., C. Barbante, C. Boutron, P. Gabrielli, V. Gaspari, P. Cescon, and L. MauriceBourgoin. 2004. Atmospheric heavy metals in tropical South America during the past 22000 years recorded in a high altitude ice core from Sajama, Bolivia. Journal of Environmental Monitoring 6(4): 322-326.

Huang, J., S. Kang, Q. Zhang, M. G. Jenkins, J. Guo, G. Zhang, and K. Wang. 2012. Spatial distribution and magnification processes of mercury in snow from high-elevation glaciers in the Tibetan Plateau. Atmospheric Environment 46: 140-146.

Mast, M. A., D. J. Manthorne, and D. A. Roth. 2010. Historical deposition of mercury and selected trace elements to high-elevation National Parks in the Western US inferred from lakesediment cores. Atmospheric Environment 44(21): 2577-2586.
Reynolds, R. L., J. S. Mordecai, J. G. Rosenbaum, M. E. Ketterer, M. K. Walsh, and K. A. Moser. 2010. Compositional changes in sediments of subalpine lakes, Uinta Mountains (Utah): Evidence for the effects of human activity on atmospheric dust inputs. Journal of Paleolimnology 44(1): 161-175.

Schuster, P. F., D. P. Krabbenhoft, D. L. Naftz, L. D. Cecil, M. L. Olson, J. F. Dewild, and M. L. Abbott. 2002. Atmospheric mercury deposition during the last 270 years: A glacial ice core record of natural and anthropogenic sources. Environmental Science and Technology 36(11): 2303-2310.

Thompson, D., G. Tootle, G. Kerr, R. Sivanpillai, and L. Pochop. 2011. Glacier variability in the Wind River Range, Wyoming. Journal of Hydrologic Engineering 16(10): 798-805.

VanLooy, J. A., R. R. Forster, D. Barta, and J. Turrin. 2013. Spatially variable surface elevation changes and estimated melt water contribution of Continental Glacier in the Wind River Range, Wyoming, USA: 19662011. Geocarto International 28(2): 98-113. 